\title{
An empirical evaluation of the effectiveness of share recommendations by stockbrokers and investment advisory services in South Africa
}

\author{
N. Bhana \\ Gradume School of Business, University of Durban-Westville, Private Bag X54001, Durban 4000, Republic of South Africa
}

\begin{abstract}
The objective of this study is to determine if the buy and sell rocommendations of stockbrokers and investment advisory services have proyided clients with superior returns during the period 1979-88. Superior returns were asociated primarily with buy, rather than sell, recommendations. The recommendations were associated with gemuine changes in the value of securities and were not mere self-fulfilling prophecies. The apparent ability of stockbrokers/investment advisory services to offer their clients superior investment recommendations may be due to their superior access to new information which they process more quickly and efficiently than most investors. Investment analysts also appear to have a potential for acquiring inside information and this in tum may have contributed to their superior retums.

Die doel van hierdie studie is om vas te stel of die aanbevelings van aandelemakelaars en beleggingsadviescienste on te koop of te verkoop wel gelei het tot beter opbrengste vir hul kliënte gedurende die tydperk 1979-88. Beter opbrengste het hoofsaaklik verband gehou met aanbevelings om te koop, cerder as om te verkoop. Die aanbevelings het verband gehou met werklike veranderinge in die waarde van beleggings en was nie selfvervullende voorspellings nie. Die klaarblyklike vermoë van aandelemakelaars en beleggingsadviesdienste om an hulle kliente beter beleggingsvoorstelle te maak, word bepaal deur die toegang wat hulle het tot nuwe inligting wat hulle vinniger en meer doeltreffend kan verwerk as meeste ander beleggers. Beleggingsontleders het ook die vermoz om eerstehandse inligting te bekom, wat bydra tot hulle uitstaande opbrengste.
\end{abstract}

\section{Introduction}

Stockbrokers' analysts and subscription investment advisory services are responsible for a significant proporion of original research related to share price movements on the Johannesburg Stock Exchange (JSE). The findings of these researchers are communicated to, and utilized by, virually all porfolio managers of institutional investors (insurance companies, pension funds, unit trusts, etc.). Furthermore, many individual investors rely predominantly or entirely on such external research. Therefore, it is important to evaluate the quality of the information and the forecasts that usually take the shape of 'buy' and 'sell' recommendations. The growth of institutional research services has raised questions regarding the extent to which external research can replace or be combined with internal research. Such an evaluation will help investors in deciding how much weight to place on the flood of share recommendations that emanate from institutional research services. From a capital market's perspective, it is important to know if the various investment advisory services possess forecasting ability related to share recommendations. Such information will also assist in deciding on whether the JSE is an efficient market, a question which is of vital importance to all investors in South Africa.

In recent years there has been a spectacular growth in institutional research output. The reasons for this growth are the expanding monetary value of institutionally managed portfolios, increasing investment emphasis on ordinary shares, and increase in portfolio tumover. The purpose of this paper is to add to the existing performance measurement literature by evaluating the investment advice of leading stockbrokers and subscription investment advisory services in South Africa. This paper describes the empirical study which tests whether the share recommendations arising from research output have been translated into superior investment performance.

\section{Efficient market hypothesis and security analysis}

The academic's view and the practitioner's view as to the nature of stock market and the value of share selection are diametrically opposed.

The academic view depicts an efficient market in which new information is immediately available at minimal cost to the investment community. Coupled with negligible transaction costs, share prices will immediately adjust to reflect new information. The academic view is expressed by the Efficient Market Hypothesis (EMH) as propounded by Fama (1970). According to the EMH each security at any point in time is priced fairly with respect to its value. In the efficient stock market model, no investor can consistently achieve abnormally high returns, and the benefits of security analysis cannot be expected to exceed the cost of trading (Vasicek \& McQuown, 1972).

The strong form of the EMH predicts that an analysts' recommendation would result in no share price adjustment at all. A weaker version would allow the recommendation to carry information but predicts that prices will adjust as soon as the analyst's clients have access to the information. Under this version, clients act as arbitrageurs, purchasing undervalued shares in anticipation of abnormal returns. As long as a share is undervalued, clients continue to purchase, and ultimately the information contained in the recommendation is completely reflected in the price.

Davies (1975) has raised an objection to the arbitrage argument. He argues that as an analyst's clients buy a particular share on his recommendation, their portfolios become more and more unbalanced, that is, they begin to assume increasing amounts of diversifiable risk. This increasing risk can bring their arbitrage operation to a 
halt before the abnormal retums are eliminated, since, at some point the abnormal returns become fair returns for an abnormal risk. Therefore, a single-investor arbitrage model may not be applicable in a world of uncertainty, where generally the risk of buying or selling short large quantities of one share cannot be fully insured by compensating portfolio adjustments. In such situations even investors with inside information will have a limited demand for undervalued shares. Under these conditions, prices will not completely adjust until the information is known to more than a few analyst's clients. Therefore, as the information becomes more widespread, further price adjustments will occur.

The practitioner or traditional view is that security markets are not perfect i.e. actual price will not always equal value. Portfolio managers and analysts can attain consistently superior retums, per units of risk accepted, by share selection resulting in a nondiversified portfolio. Analysts utilize a number of fundamental and technical approaches to isolate shares whose prices and values are divergent. By discovering a change in a company's future earning stream, or a change in the probability distribution of that stream, the analyst can, in an imperfect market, preempt the market process and thereby profit. Implicit in this view of the market is that share prices do not instantaneously adjust to new information and that knowledge and analysis are important and can lead to share selections yielding above-average returns.

Boldt and Arbit (1984) have traced and evaluated the empirical evidence supporting, as well as contradicting, the EMH. They have observed that the case for all forms of EMH is neither as strong as most academics assume, nor as weak as most professional investors like to believe. Rosenburg and Rudd (1982) have demonstrated that the earlier empirical evidence in support of EMH seems to pale in comparison with the results of later studies using more efficient statistical procedures, which have uncovered a wealth of 'anomalous evidence' against the EMH. Rohrer (1985) cites examples to show that security markets constitute a broad spectrum of efficiency, which on one end is 'hyperefficient' instantly adjusting prices to new information - and on the other end is seemingly inefficient, where market prices are a poor relation of true values.

Professional investors should not reject the EMH out of hand, despite the recent studies providing evidence contradicting it. The economic rationale in support of market efficiency is strong and carries valuable lessons for investors. Investors should think twice before acting simply because they assume they have better than average information. The typical presumption that hiring above-average researchers and allowing them to exercise their abilities will make EMH somehow irrelevant scems a dangerously myopic view. Taking a long-term view, trading carefully and searching for opportunities caused by a bias in conventional thinking seem to be the keys to success for professional investors in a highly competitive, but not strictly efficient market.

\section{Previous studles}

Strong form tests of market efficiency are concerned with whether given investors or groups have monopolistic access to non-public information relevant to price formation. Unfortunately, there is no clear cut distinction between public and private information, nor is it clear when information becomes public, nor which investors are in the public. Stockbrokers' analysts, for example, utilize both public and private information. The latter is obtained from company visits, special relationships with companies and their personnel, or may be generated as 'private insights' derived from public information. When their forecasts are communicated to clients, there will be uncertainty about when they enter the public domain. These overlaps and ambiguities make it difficult to draw a clear distinction between semistrong and strong form tests of efficiency. Nevertheless, studies of analysts' forecasting ability have always been regarded as mainstream strong form tests. In practice, virtually all strong form tests proceed by first identifying a group with potential access to private information, and then testing for evidence of persistent abnormal returns.

Cowles (1933) undertook the earliest investigation of the quality of professional investment counsel by examining the securities recommendations of 16 financial services, 25 financial publications and the editors of The Wall Street Joumal. He concluded that the shares recommended typically underperformed broad market averages by some one to four per cent per annum in periods immediately following the observed recommendations. Colker (1963) and Diefenbach (1972) appraised the share selections of a group of institutional brokerage firms during the 1960's. Neither studies found much evidence of expertise, the evidence suggesting that an investor who accepted the advice offered would have ended up doing as well as the market's overall trend.

Logue and Tuttle (1973) reached essentially the same conclusion in a study of the securities recommended by six major brokerage houses. The analysis involved a comparison of retums on these securities (over holding periods of three, six and twelve months after the recommendations appeared) with concurrent returns on randomly selected portfolios. In general, they found little difference in aggregate performance - although, one of the firms considered did in fact seem to have fairly consistent success in picking winners. Investigations by Cheney (1969) and Black (1973) of the recommendations of several investment advisory services detected signs of some apparent ability on the part of professionals to identify securities that would provide a superior retums in the post-recommendation period.

A study by Davies and Canes (1978) provides some evidence that recommendations by Wall Street analysts 
can be successful if acted on before such information becornes widespread. The same general conclusion was reached by Dimson and Marsh (1984) who studied over $\mathbf{4 0 0 0}$ specific retum forecasts made by 35 British stockbrokers and by the internal analysts of a large United Kingdom investment institution. While a large part of the information content of a new forecast appears to be discounted in the marketplace during the first month, transactions implemented at the time could have been transhated into superior performance by portfolio managers. Interestingly, the study also showed that differences in forecasting ability among the brokers studied did not appear to persist over time, but that predictive accuracy could have been improved by pooling simultancous forecasts from different sources.

A study by Groth, Lewellen, Schlarbaum and Lease (1979) of one brokerage house's recommendation to its individual clients during the 1960's suggests that they were genuinely valuable, even after allowing for transaction costs and risk. $O n$ the other hand the recommendations were useful in selection, rather than in market timing. Bjerring, Lakonishok and Vermaelen (1983) reviewed the recommendations of a leading Canadian brokerage house and concluded that following the analysts recommendations would have created significantly positive abnormal returns, even after allowing for transaction costs. The strong form of the EMH holds that this should not happen. These findings tend therefore to refute the strong form of the EMH.

Numerous studies of the performance of share recommendations, in the United States, United Kingdom, Australia and Hong Kong, have in fact been published. Typically, some form of residual analysis is used to identify any abnormal retum behaviour from shares for which there have been buy, hold or sell recommendations. The results of these studies have been summarized by Dimson and Marsh (1984). The findings indicate a small degree of forecasting ability, at least before dealing costs are taken into account. The profit opportunities disclosed by these studies are, however, limited. Share purchases at the pre-publication price are on average profitable, but purchases made a few days or a week after recommendation offer no opportunity for systematic abnormal gains.

In summary, previous studies of the performance recommendations made by stockbrokers and investment advisory services indicate a small but potentially useful degree of forecasting ability. In cases where recommendations are made public, most of the information content appears to be impounded into share prices by the end of the publication day. Even for analysts' predictions which are not made public, forecasts provide their greatest explanatory power in the carly months immediately after the forecast. Despite the proliferation of studies in this field, the existing evidence remains controversial. Coggin and Hunter (1983) have pointed out that small-sample studies and the possibility of selection bias have reduced the reliability of many investigations into the efficiency of share recommendations.

\section{Investment advisory services in South Africa}

To date, no studies have been conducted into the efficiency of the various investment advisory services in South Africa. However, a recent study investigated the ability of investment analysts in South Africa to predict and interpret the earnings performance of companies listed on the JSE. Knight and Affleck-Graves (1985) have presented evidence which indicates that South African investment analysts are not efficient in anticipating superior earnings performance and poor earnings performance. Knight and Affleck-Graves (1985: 159) conclude that investors on the JSE are reasonably efficient in that once new information is released, share prices adjust rapidly to a new equilibrium level.

Lease, Lewellen and Schlarbaum (1974) have shown that investors regard brokerage houses and investment advisory services as the most useful sources of investment information. While this observation was made for investors in the United States, it applies with equal force to the South African situation. For this reason, this investigation has included representative publications from each of these sources. These publications are available to individual investors in brokerage house offices and public libraries as well as through personal subscriptions.

The growth in the number of investors on the JSE and advances in computer technology has resulted in a proliferation of subscription advisory services in South Africa. The investment recommendations are provided in the form of newsletters which are usually distributed on a weekly or monthly basis. The annual subscription fee runs into several hundreds of rands. Therefore, the investment advisory services tend to attract clients that are active traders. Investment advisory services use a combination of fundamental analysis and technical analysis on which to base their investment recommendations. However, there are certain advisory services that rely exclusively on technical analysis (chartism).

Stockbrokers research publications constitute a second source of investment guidance. Most stockbrokers provide their active clients with such literature on a quarterly, monthly or weekly basis. Although the stockbrokers research publications are distributed free of charge, they are only distributed to clients making substantial investments. In addition to commenting on the state of the market brokerage reports also describe shares that have unusual investment potential and 'special situations'. Stockbroker research undertaken by large firms tends to be highly specialised. Usually several teams of researchers are employed to evaluate the investment prospects of specific sectors and categories of companies listed on the JSE.

A common feature of the two categories of publications is that they provide their readers with buy and sell recommendations. The buy recommendations tend to outnumber the sell recommendations. These publications seldom reverse their suggested strategies by 
advising readers to sell previously recommended shares. More frequently recommendations are changed from 'buy' to 'hold' for further discussion. At times a qualified recommendation of 'buy on weakness' is made. Complicating the issue is that different investors may have varied interpretations of the 'hold' and 'buy on weakness' recommendations.

\section{Research data}

Two large firms of stockbrokers and two firms providing investment advisory services on a subscription basis to clients agreed to participate in this investigation. The brokerage firms and the investment advisory services firms provided an access to documents in their historical file of research reports and share recommendations. From these records a list of all the share recommendations made by these firms during the ten-year period from January 1979 through December 1988 was compiled. The date on which each recommendation first appeared was checked for accuracy and completeness. All shares considered were listed on the JSE and for which market prices and dividend information was readily available. Although the firms concerned supply their clients with various types of share recommendations, only 'buy' and 'sell' recommendations are considered for this investigation.

The intention of this study is to measure the efficiency of the recommendations made by stockbrokers and investment advisory services. Therefore, the share performance of recommendations made by these two groups are compared and contrasted to determine their relative forecasting abilities. For both the buy and sell recommendations, a random sample 100 shares recommended by brokerage firms and 100 shares recommended by investment advisory services were chosen for analysis.

\section{Research methodology}

According to the capital asset pricing model (CAPM) developed by Sharpe (1964) and Lintner (1965), there should be, in a well-functioning capital market environment, a linear relation between the expected retum on a security and the security's contribution to portfolio risk. Despite the critique by Roll (1977) regarding the empirical testability of the CAPM, all studies of market efficiency must either assume such a model, or else make equally strong assumptions about the stability of the return-generating process. A commonly used technique is the Market Model (Bowman, 1983), which employs simple linear regression to estimate the required risk-adjusted return for a security. The abnormal returns associated with share recommendations were estimated by means of the Market Model:

$R_{j}^{*}=q+\beta R_{m t}+\varepsilon_{j}$

where $R_{j \mathrm{j}}^{*}=$ the expected retum on share $\mathrm{j}$ for the period $\mathrm{t}$; $\alpha, \beta=$ the intercept and slope respectively of the linear relationship between the return for share $j$ and the returns for the general market; $R_{m b}=$ retum on the market portfolio represented by the JSE Overall Actuaries Index during period t: $\bar{E}=$ disturbance term or residual.
The estimated abnormal retum is given by the expression:

$\epsilon_{\mathrm{k}}=R_{\mathrm{k}}^{*}-\left(\hat{\alpha}_{\mathrm{j}}+\hat{\beta}_{\mathrm{j}} \mathbf{R}_{\mathrm{mt}}\right)$

where and $q$ and $\beta$ are the ordinary least square estimate of $\alpha$ and $\beta$.

We can attribute deviations of observed $R_{j k}$ from those stipulated by the Market Model i.e. $R^{*}$ to whatever special or extraordinary circumstances surrounding security $j$ during the interval considered - temporary disequilibria, some inevitable random noise in the underlying retur generating process, or the receipt of new information by investors about the security in question. The objective is to examine the deviations around the vicinity of the date of the stockbrokers/investment advisory service recommendation to its clients in order to demonstrate any apparent skill in anticipating consistently favourable (unfavourable) circumstances.

The hypothesis tested in this study can be stated as:

Ho: Stockbrokers' analysts and investment advisory services utilize a number of fundamental and technical approaches to isolate shares whose prices and 'intrinsic values' are divergent. By discovering a change in the company's future profit prospects, the analyst can, in an imperfect market, preempt the market adjustment process and thereby enable clients to benefit.

To test the hypothesis, the variable of interest is the security's 'excess' or 'residual' return, defined as: $e_{j \mathfrak{t}}=R_{j \mathfrak{j}}$ $R^{*}$. If the mean value of this quantity across the array of recommendations described above is non-zero (positive for buy recommendation; negative for sell recommendation) and statistically significant, we can draw an inference of expertise in security analysis and investment counsel on the part of stockbrokers/investment advisory services.

Weekly share prices were collected for a period of 33 weeks surrounding each share recommendation. The standard reference date for each security $(t=0)$ is the week in which a recommendation for it appeared. In every instance, return residuals were computed for the 24 weeks just prior to and for the eight weeks immediately following the recommendation. Thus the analytical interval runs from week $\mathrm{t}=-24$ through $t=+8$, spanning a variety of different calendar periods but structured always around the applicable recommendation date.

The weekly average residuals were estimated from the Market Model and may be expressed as:

$$
\mathrm{a}=\frac{1}{100} \sum_{j=1}^{100} \hat{e}_{\mathrm{jt}} \quad \mathrm{t}=-24,-23,
$$

A total of 33 average residuals were calculated i.e. for the 24 trading weeks prior to the recommendation date and the 9week period on and after the recommendation date. The average residuals were used as a basis for examining abnormal share price movements surrounding the recommendation date. The cumulative average residual (CAR), defined as the sum of the previous weekly average 
Table 1 Investment return residuals for buy recommendations by stockbrokers and investment advisory services during 1979-1988 (Primary dissemination)

\begin{tabular}{|c|c|c|c|c|c|c|}
\hline & \multicolumn{3}{|c|}{ Stockbrokers } & \multicolumn{3}{|c|}{ Investment advisory services } \\
\hline $\begin{array}{c}\text { Week } \\
\text { (t) }\end{array}$ & $\begin{array}{c}\text { Average } \\
\text { retum } \\
\text { residual } \\
\%\end{array}$ & $\begin{array}{c}\text { Equiv. } \\
\text { annual } \\
\text { rewm } \\
\%\end{array}$ & $\begin{array}{c}\text { Cumulative } \\
\text { average } \\
\text { residual } \\
\%\end{array}$ & $\begin{array}{c}\text { Average } \\
\text { retum } \\
\text { residual } \\
\%\end{array}$ & $\begin{array}{c}\text { Equiv. } \\
\text { ennual } \\
\text { retum } \\
\varnothing\end{array}$ & $\begin{array}{c}\text { Curnulative } \\
\text { average } \\
\text { residual } \\
\varnothing\end{array}$ \\
\hline-16 & $0,23^{2}$ & 11,96 & 0,23 & & & \\
\hline-15 & 0,27 & 14,04 & 0,50 & & & \\
\hline-14 & $0.18^{b}$ & 9.36 & 0,68 & $0,20^{\circ}$ & 10,40 & 0,20 \\
\hline-13 & $0,24^{4}$ & 12,48 & 0,92 & $0,23^{*}$ & 11,96 & 0,43 \\
\hline-12 & $0,26^{\circ}$ & 13,52 & 1,18 & $0,26^{4}$ & 13,52 & 0,69 \\
\hline-11 & $0,21^{\circ}$ & 10,92 & 1,39 & $0,19^{4}$ & 9,88 & 0,88 \\
\hline-10 & $0,23^{2}$ & 11,96 & 1,62 & $0,17^{\circ}$ & 8,84 & 1,05 \\
\hline-9 & $0,20^{\circ}$ & 10,40 & 1,82 & $0,20^{\circ}$ & 10,40 & 1,25 \\
\hline-8 & $0,19^{2}$ & 9,88 & 2,01 & $0,23^{\prime}$ & 11,96 & 1,48 \\
\hline-7 & $0,24^{2}$ & 12,48 & 2,25 & $0,18^{\circ}$ & 9,36 & 1,66 \\
\hline-6 & $0,20^{\circ}$ & 10,40 & 2,45 & $0,25=$ & 13,00 & 1,91 \\
\hline-5 & $0,30^{\circ}$ & 15,60 & 2,75 & $0,24^{4}$ & 12,48 & 2.15 \\
\hline-4 & $0,34^{\circ}$ & 17,68 & 3,09 & $0,29^{4}$ & 15,08 & 2,44 \\
\hline-3 & $0,28^{\circ}$ & 14,56 & 3,37 & 0,25 & 13,00 & 2,69 \\
\hline-2 & $0,29^{\circ}$ & 15,08 & 3,66 & $0,27^{\circledR}$ & 14,04 & 2,96 \\
\hline-1 & $0,32^{2}$ & 16,64 & 3,98 & $0,26^{\circ}$ & 13,52 & 3,22 \\
\hline 0 & $0,46^{2}$ & 23,92 & 4,44 & $0,34^{*}$ & 17,68 & 3,56 \\
\hline 1 & $0,29^{\circ}$ & 15,08 & 4,73 & $0,22^{a}$ & 11,44 & 3,78 \\
\hline 2 & 0,13 & 6,76 & 4,86 & 0,12 & 6,24 & 3,90 \\
\hline 3 & 0,10 & 5,20 & 4,96 & 0,08 & 4,16 & 3,98 \\
\hline 4 & 0,11 & 5,72 & 5,07 & 0,06 & 3,12 & 4,04 \\
\hline 5 & 0,10 & 5,20 & 5,17 & 0,07 & 3,64 & 4,11 \\
\hline 6 & 0,08 & 4,16 & 5,25 & 0,04 & 2,08 & 4,15 \\
\hline 7 & 0,06 & 3,12 & 5,31 & 0,05 & 2,60 & 4,20 \\
\hline 8 & 0,07 & 3,64 & 5,38 & 0,08 & 4,16 & 4,28 \\
\hline
\end{tabular}

residuals, was calculated for each trading week of the study and may be written as:

$\mathrm{CAR}_{\mathbf{t}}=\mathrm{e}_{\mathrm{t}}+\mathrm{CAR}_{\mathrm{t}-1} \quad \mathrm{t}=-24,-23$, , 8

If one assumes that there are no unusual share price movements prior to the recommendation date, one can expect that both $\mathrm{e}_{\mathrm{i}}$ and $\mathrm{CAR}_{4}$ would fluctuate randomly about zero. However, if stockbrokers/investment advisory services do provide valuable investment advice to their clients and there is trading on the basis of the recommendations, this would be reflected for buy (sell) recommendations by positive (negative) weekly average residuals and corresponding build up in CAR.

The sample population has been stratified according to stockbrokers' and investment advisory services recommendations. The purpose for doing this is to determine whether stockbrokers as a group or investment advisory services as a group were able to offer superior share recommendations to their clients during the period of the investigation.

\section{Empirical results}

For the first test, random samples were drawn for 100 buy recommendations made by stockbrokers and investment advisory services to their clients. The weekly average retum residuals $\left(e_{1}\right)$ for each sample of buy recommendation for the 1979-1988 investigation period are given in Table 1 and Figure 1. In Figure 1, the average residuals for the recommendations made by investment advisory services are not shown as they follow a trend very similar to that of stockbrokers' recommendations.

For the buy recommendations made by stockbrokers, the average return residuals are uniformally positive for the entire period under investigation. However, the average return residuals are statistically significant only for the 16 weeks prior to, for the recommendation week itself, and the week following the recommendation. The differential investment results implied, range from an annualized rate of return of approximately 9 per cent in excess of that realisable concurrently from a diversified portfolio of comparable-risk securities up to a return - in the week of recommendation about 24 per cent better than such a benchmark. After the 
week of recommendation, the results are statistically indistinguishable from zero. The CAR, value during the 26week period is $5,38 \%$. These results clearly indicate that share purchases on the basis of recommendations by stockbrokers at the pre-publication price are on average profitable; but purchases made a week after the recommendation offer no opportunity for systematic abnormal gain.

It can be seen from Table 1 that the purchase recommendations by investment advisory services also enabled their clients to enjoy superior market performance. However, on average, the weekly return residuals have lower values than the corresponding recommendations by stockbrokers. The CAR value of $4,28 \%$ is also substantially lower than the corresponding value of $5,38 \%$ for recommendations made by stockbrokers. The results suggest that the buy recommendations of stockbroker analysts' were of greater economic value to their clients than the corresponding recommendations made by investment advisory services.

For the second test, random samples were drawn for 100 sell recommendations made by stockbrokers, and investment advisory services to their clients. The results for the 1979-1988 period of investigation are shown in Table 2 and Figure 2. In Figure 2, the average retum residuals for the sell recommendations made by investment advisory services are not shown as they follow a trend very similar to that of stockbrokers' recommendations.

For the sell recommendations by stockbrokers, the average return residuals follow a random pattern until 15 weeks prior to the recommendation date. From week 14 to week 5 prior to the recommendation date, the return residuals are negative but not statistically significant. Negative and statistically significant average residuals are observed during the 4 weeks preceding, and the week following the recommendation date. The average residuals are equally divided between positive and negative values after the week following the recommendation date. The pattern of results for the sell recommendations by investment advisory services are similar, with both the and the $e_{t}$ and the $C A R_{\text {q }}$ values somewhat lower than those for the recommendations by stockbrokers. These results suggest that as in the case of buy recommendations, the sell recommendations of stockbrokers were of greater economic value to their clients than the corresponding recommendations made by investment advisory services.

Comparing the results of the buy and sell recommendations reveal several important observations. First, the sell recommendations underperform the market the average residuals were slightly lower than a portfolio of similar risky securities. Second, the buy recommendations were, on average, more beneficial than sell recommendations to the clients of these institutions. The buy recommendations provided greater abnormal returns which persists for a longer period than the corresponding sell recommendations. Therefore, clients following a buy recommendation are more likely to benefit than those clients reacting to a sell recommendation. The extraordinary returns associated with

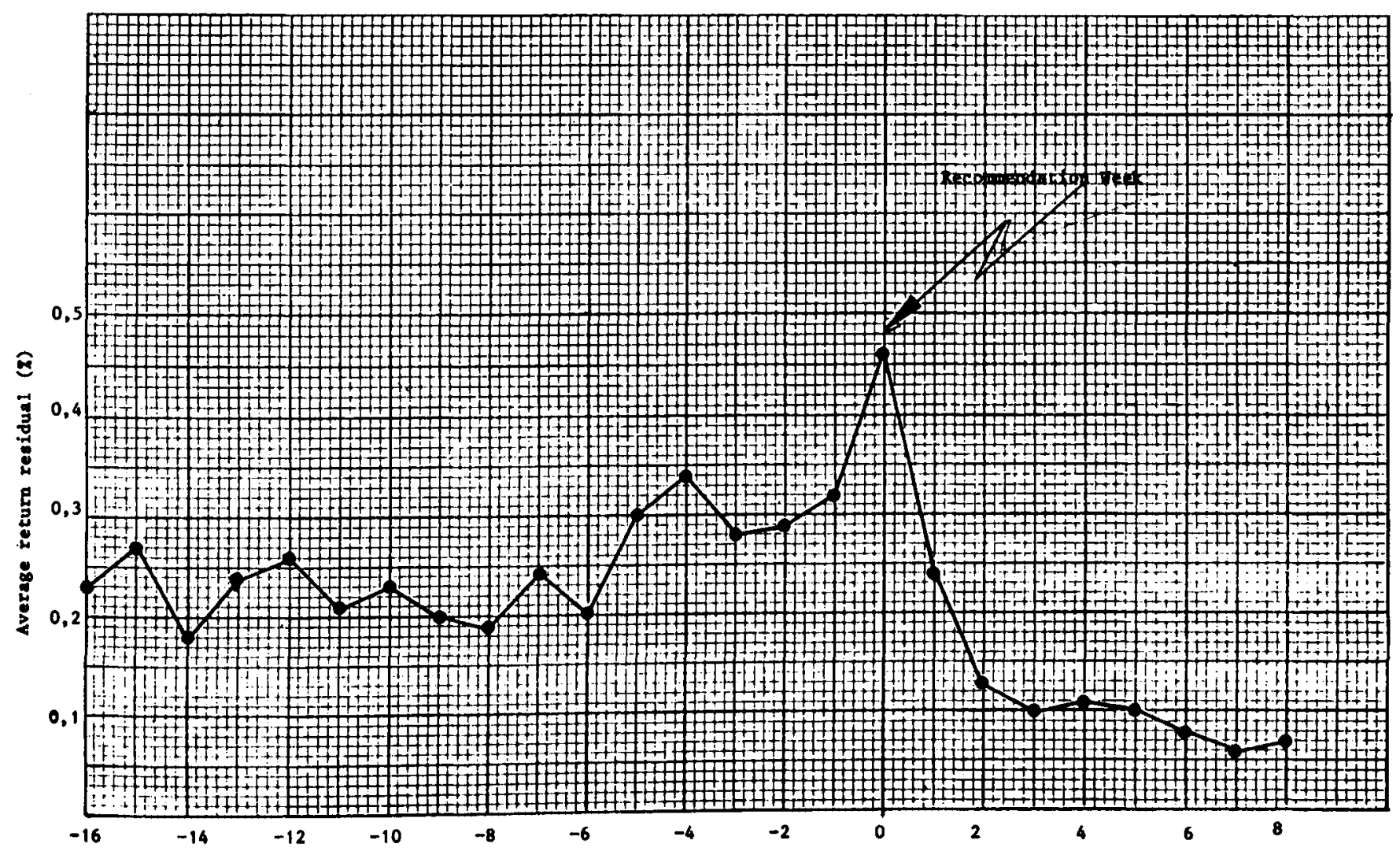


Table 2 Investment return residuals for sell recommendations by stockbrokers and investment advisory services during 1979-1988 (Primary dissemination)

\begin{tabular}{|c|c|c|c|c|c|c|}
\hline & \multicolumn{3}{|c|}{ Stockbrokers } & \multicolumn{3}{|c|}{ Investment advisory services } \\
\hline $\begin{array}{l}\text { Woek } \\
(t)\end{array}$ & $\begin{array}{l}\text { Average } \\
\text { retum } \\
\text { residual } \\
\%\end{array}$ & $\begin{array}{c}\text { Equiv. } \\
\text { annual } \\
\text { rewam } \\
\%\end{array}$ & $\begin{array}{c}\text { Cumulative } \\
\text { average } \\
\text { residual } \\
\%\end{array}$ & $\begin{array}{l}\text { Average } \\
\text { retum } \\
\text { residual } \\
x_{0}\end{array}$ & $\begin{array}{c}\text { Equiv. } \\
\text { annual } \\
\text { retum } \\
\%\end{array}$ & $\begin{array}{c}\text { Cumulative } \\
\text { average } \\
\text { residual } \\
\text { \% }\end{array}$ \\
\hline-14 & $-0,04$ & $-2,08$ & $-0,04$ & & & \\
\hline-13 & $-0,06$ & $-3,12$ & $-0,10$ & $-0,05$ & $-2,60$ & $-0,05$ \\
\hline-12 & $-0,03$ & $-1,56$ & $-0,13$ & $-0,04$ & $-2,08$ & $-0,09$ \\
\hline-11 & $-0,07$ & $-3,64$ & $-0,20$ & $-0,08$ & $-4,16$ & $-0,17$ \\
\hline-10 & $-0,09$ & $-4,68$ & $-0,29$ & $-0,06$ & $-3,12$ & $-0,23$ \\
\hline-9 & $-0,03$ & $-1,56$ & $-0,32$ & $-0,03$ & $-1,56$ & $-0,26$ \\
\hline-8 & $-0,11$ & $-5,72$ & -0.43 & $-0,09$ & $-4,68$ & $-0,35$ \\
\hline-7 & $-0,10$ & $-5,20$ & $-0,53$ & $-0,08$ & $-4,16$ & -0.43 \\
\hline-6 & $-0,12$ & $-6,24$ & $-0,65$ & $-0,10$ & $-5,20$ & $-0,53$ \\
\hline-5 & $-0,16$ & $-8,32$ & $-0,81$ & $-0,14$ & $-7,28$ & -0.67 \\
\hline-4 & $-0,18^{t}$ & $-9,36$ & $-0,99$ & $-0,17$ & $-8,84$ & $-0,84$ \\
\hline-3 & $-0,20^{\circ}$ & $-10,40$ & $-1,19$ & $-0,19$ & $-9,88$ & $-1,03$ \\
\hline-2 & $-0,22^{a}$ & $-11,44$ & $-1,41$ & $-0,18^{b}$ & $-9,36$ & $-1,21$ \\
\hline-1 & $-0,25^{a}$ & $-13,00$ & $-1,66$ & $-0,22^{n}$ & $-11,44$ & -1.43 \\
\hline 0 & $-0,38^{\circ}$ & -19.76 & $-2,04$ & $-0,33^{2}$ & $-17,16$ & $-1,76$ \\
\hline 1 & $-0,30^{\circ}$ & $-15,60$ & $-2,34$ & $-0,31^{2}$ & $-16,12$ & $-2,07$ \\
\hline 2 & $-0,14$ & $-7,28$ & $-2,48$ & $-0,13$ & $-6,76$ & $-2,20$ \\
\hline 3 & $+0,09$ & $+4,68$ & $-2,39$ & $+0,08$ & $+4,16$ & $-2,12$ \\
\hline 4 & $+0,11$ & +5.72 & $-2,28$ & $-0,09$ & $-4,68$ & $-2,21$ \\
\hline 5 & $-0,09$ & $-4,68$ & $-2,37$ & $+0,13$ & $+6,76$ & $-2,08$ \\
\hline 6 & $+0,12$ & $+6,24$ & $-2,25$ & $-0,14$ & $-7,28$ & $-2,22$ \\
\hline 7 & $-0,14$ & $-7,28$ & $-2,39$ & $+0,08$ & $+4,16$ & $-2,14$ \\
\hline 8 & $+0,07$ & $+3,64$ & $-2,32$ & $+0,06$ & $+3,12$ & $-2,08$ \\
\hline
\end{tabular}

• = significant at 0,01 level; $"=$ significant at 0,05 level

the securities that were the focus of stockbrokers/advisory services investment recommendations were therefore, almost entirely due to the buy recommendations.

The relatively poor performance of the sell recommendations probably explains the reluctance of investment advisors to make such recommendations. Over the study period there were relatively few sell recommendations by the stockbrokers/investment advisory services whose investment advice formed the basis of this investigation. The local position is consistent with the observation by Shepard (1977) that the buy recommendations outnumber the sell recommendations by a ratio of 25 to 1 . Despite frequent protestations to the contrary, analysts apparently remain reluctant to go on record as recommending sale of shares. Probable reasons for this reluctance include (1) the long-term upward trend in share prices in general (2) the danger of incurring the animosity of a valued management contact, or in some cases, a valued corporate client, (3) the somewhat lesser marketability of sell recommendations (due to a limited number of existing holders), (4) the net cash inflow enjoyed by most institutional investors, and (5) income tax implications.

Several reasons can be suggested for the apparent ability of stockbrokers/investment advisory services to offer their clients superior investment recommendations. First, it can be argued that they have superior access to new information which they process more quickly and more efficiently than most investors. These institutions operate in an environment which offers them a relatively favourable position in the profession. They enjoy the full range of modern technological developments in the areas of data processing, field research and security analysis. In addition, these institutions also employ several specialists such as economists, statisticians and investment analysts to assist in the generation of research. Generally, stockbrokers have greater research facilities than investment advisory services. Also, there is a far greater degree of specialization in the research carried out by stockbrokers (industrial shares, goldmining shares, financial services sector, etc.). The superior research facilities enjoyed by the stockbrokers may explain their ability to outperform the advisory services when making share recommendations.

The possession of material inside information by stockbrokers/investment advisory services, before it is publicly disclosed could be another reason for their superior share recommendations. Both these groups make regular 


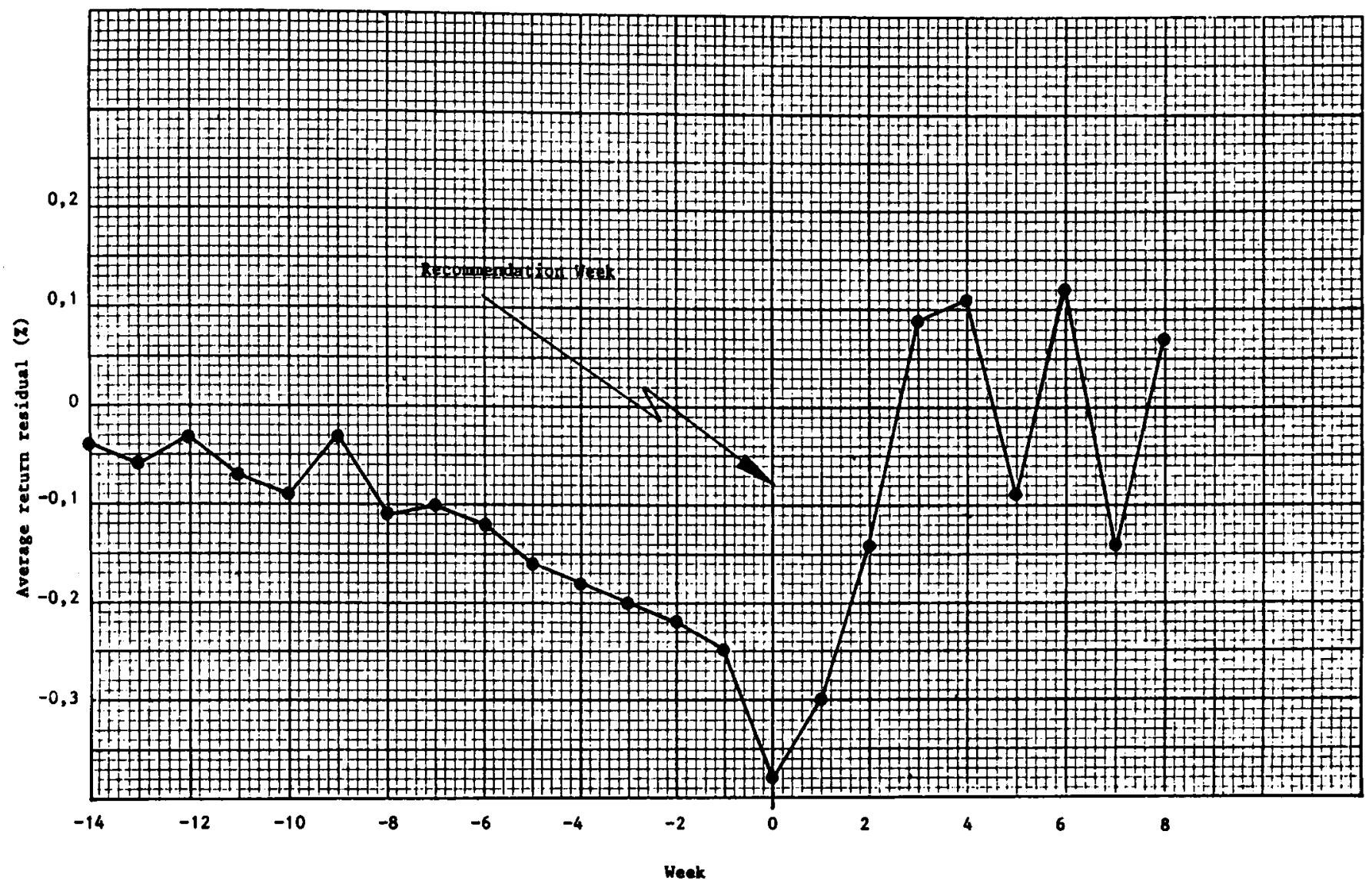

Figure 2 Weekly investment retum residuals for sell recommendations by stockbrokers

company visits to seek new information. Often the new information obtained is not confidential, but if combined with other publicly available information, may provide new insights into the company's future prospects. Sometimes, material information is obtained from company insiders which has not been publicly disclosed. Stockbrokers are multi-function firms which provide diverse services such as corporate finance, portfolio management, share broking and investment advisory service to clients. In providing a particular function (corporate finance) the stockbroking firm may well acquire inside information which could be used by a division providing another service to clients (investment advisory service). In terms of the recently promulgated Companies Amendment Act relating to insider trading, such exchange of non-public information between the different divisions of a multi-function firm is illegal (Greenblo, 1989).

The large stockbroking firms operating on the JSE are invariably multi-function firms. Therefore, the potential to acquire material information before it is publicly disclosed is substantial. Prior to the new Companies Amendment Act, prohibition on insider trading was virtually unenforceable because of the many limitations and anomalies in the legislation (Bhana, 1987). The period covering this investigation falls within the ambit of Section 233 of the Companies Act, and investment advisors may well have utilized inside information without breaching insider trading regulations because of the deficiency in the old legislation. Stockbroking firms have a great potential to acquire inside information and this in turn may have contributed towards their superior recommendations.

There is another possible explanation for the superior buy recommendations of stockbrokers/investment advisory services. It is submitted that in the months immediately preceding the buy recommendation, the companies concerned enjoyed periods of abnormal prosperity. It can be expected that these favourable news items were communicated through normal news media channels to the investment community. This in tum induced steady upward revisions in investor expectations about the prospects of the companies involved. This is confirmed by the observed superior investment results during the pre-recommendation weeks.

The superior performance of the companies in question ultimately caught the attention of the research staff of stockbrokers/investment advisory services. Further detailed analysis is likely to uncover additional favourable information, which is communicated in the form of investment recommendations to its clients. The resulting market reaction accelerated the impact of favourable news, which otherwise would have required several months to be digested. The rapid price change that took place in the recommendation week and the week immediately following it, fully exhausted the remaining upward revisions in expectations. As a consequence, the security returns reverted to their normal relationships with the market, and the superior abnormal returns disappeared.

This explanation offers a reasonable interpretation of 
superior investment research and is consistent with the notion of market efficiency. Formal professional investment research promotes market efficiency by speeding up the flow of information to investors. This view is supported by the observation that the superior abnormal returns become statistically insignificant within a week after publication of the recommendations. This suggests that the investor response to recommendations reflects 'real' information and that the analysts' recommendations are not self-fulfilling prophecies. If the investment recommendations are based on contrived information they will give rise to higher returns than normal at the time of publication but lower retums than normal later on. Since no such price reversal is detected for the buy recommendations, it can be concluded, that analysts' recommendations have positive economic value and are not mere self-fulfilling prophecies.

Although the abnormal retums are statistically significant for a period of one week after publication, it is unlikely that all clients of stockbrokers/investment advisory services benefitted from responding to the recommendations. First, it is unlikely that the research publications reached all clients at the same time. Second, only a minority of the clients may have been in a position to respond to any given recommendation and only those who acted quickly may have succeeded in outperforming the market. Therefore, the enduring value of investment recommendations is that it creates an efficient market by speeding up the flow of new information to investors.

\section{Conclusions}

The results of this investigation show that both the stockbrokers and investment advisory services provided a valuable service to their clients in selecting shares which achieved positive abnormal returns during the recommendation period. Moreover, the information content of the recommendations was not 'immediately' reflected in market prices. The findings of this investigation are similar to those observed by overseas researchers who have demonstrated that clients of investment analysts could have achieved superior abnormal retums by following the recommendations. The results are consistent with the hypothesis that (at least some) investment analysts make the market efficient by passing on information to their clients. The recommendations were associated with genuine changes in the value of securities and were not mere self-fulfilling prophecies.

\section{Acknowledgements}

The financial assistance of the Institute for Research Development of the Human Sciences Research Council towards this research is hereby acknowledged. Opinions expressed in this publication and conclusions arrived at, are those of the author and do not necessarily represent the views of the Institute for Research Development or the Human Sciences Research Council.

\section{References}

Bhana, N. 1987. Take-over announcements and insider trading activity on the Johannesburg Stock Exchange, S. Afr. J. Bus. Manage., Vol. 18: 198-208.

Bjerring, J.H., Lakonishok, J. \& Vermaelen, T. 1983. Stock prices and financial analysts' recommendations, J. Fin., Vol. 38: 187-204.

Black, F. 1973. Yes Virginia, there is hope: Test of the value line ranking system. Financial Analysts Journal, Vol. 29: $10-14$.

Boldt, B.L. \& Arbit, H.L. 1984. Efficient markets and the professional investor. Financial Analysts Journal, Vol. 40: 22-34.

Bowman, R.C. 1983. Understanding and conducting event studies, J. Bus. Fin. \& Acc., Vol. 10: 561-584.

Cheney. H. 1969. How good are investment advisory services? Fin. Exec., Vol. 37: 30-35.

Coggin, T.D. \& Hunter, J.W. 1983. Problems in measuring the quality of investment information: The perils of the information coefficient, Financial Analysts Journal, Vol. 39: 18-22.

Colker, S. 1963. An analysis of security recommendations by brokerage houses, $Q$. Rev. Econ. \& Bus., Vol. 3: 19-28.

Cowles, A. 1933. Can stockmarket forecasters forecast? Econometrica, Vol. 1: 309-324.

Davies, P.L. 1975. Speculation, market efficiency and pareto optimality in an uncertain capilal market. Working paper no. 7537. University of Rochester, Graduate School of Management.

Davies, P.L. \& Canes, M. 1978. Stock prices and the publication of second-hand information, J. Bus., Vol. 51: 43-56.

Diefenbach, R.E. 1972. How good is institutional brokerage research? Financial Analysts Journal, Vol. 28: 54-60.

Dimson, E. \& Marsh, P. 1984. An analysis of brokers' and analysts' unpublished forecasts of UK stock returns. $J$. Fin., Vol. 39: 1257-1292.

Fama, F.F. 1970. Efficient capital markets: A review of theory and empirical work. J. Fin., Vol. 25: 383-417.

Greenblo, A. 1989. Inside out - New securities legislation not as confusing as many fear. Fin. Week, Vol. 42: 3-4.

Groth, J.C., Lewellen, W.G., Schlarbaum., G.G. \& Lease,

R.C. 1979. An analysis of brokerage house securities

recommendations. Financial Analysts Journal, Vol. 35: 32-40.

Knight, R.F. \& Affleck-Graves, J.F. 1985. An empirical evaluation of the effectiveness of South African investment analysts. S. Afr. J. Bus. Manage., Vol. 16: 157-160.

Lease, R.C., Lewellen, W.G., \& Schlarbaum, G.G. 1974. The individual investor: Attributes and attitudes. J. Fin., Vol. 29: $413-433$

Lintner, J. 1965. The valuation of risk assets and the selection of risky investments in stock portfolios and capital budgets. Rev. Econ. \& Statis., Vol. 47: 13-37.

Logue D. \& Tuttle, D. 1973. Brokerage house investment advice. Fin. Rev., Vol. 8: 38-54.

Rohrer, J. 1985. Who says you can't beat the market. Instiutional Investor, July, 141-146.

Roll R. 1977. A critique of asset pricing theory's test; Part 1: 
On past and potential testability of the theory. J. Fin. Econ., Vol. 4: 129-176.

Rosenberg, B. \& Rudd, A. 1982. Factor-related and specific returns of common stocks: Serial correlation and market inefficiency. J. Fin., Vol. 37: 543-554.

Sharpe, W.F. 1964. Capital asset prices: A theory of market equilibrium under conditions of risk. J. Fin., Vol. 19: 425-442.

Shepard, L. 1977. How good is investment advice for individuals? J. Portfolio Manage., Vol. 3: 32-36.

Vasicek, O.A. \& McQuown, J.A. 1972. The efficiency model. Financial Analysts Journal, Vol. 27: 73-76. 